\title{
우리나라의 대 개발도상국 교과서 보급사업의 성과와 향후 추진 방향
}

최 영 렬 ${ }^{1)}$ 한국직업능력개발원 연구위원

\section{목차}

I. 서론

II. 라오스 교과서 보급사업 개요 및 성과

III. 주요 선진국 및 국제기구의 교과서 보급사업

IV.향후 교과서 보급사업 추진 방향

\section{I. 서론}

교육을 통한 인적자원개발은 지속 가능한 경제발전을 이끄는 원동력 중의 하나로 인식되고 있다. 우리나라의 인적자원개발은 세계 역사상 유례없이 단기간에 놀라운 경제성장을 이룩한 대한민국의 성공요인의 하나로 평가된다. 또한 교육에 대한 집중적 투자는 개발도상국들이 빈곤에서 벗어나기 위해 수립하는 중요한 경제발전 전략 중 하나이다. 우리나라도 해방 이후 급속한 경제발전을 추구 하는 과정에서 경제발전에 필요한 인력을 교육을 통해 제공받았음은 주지의 사실이다.

그러나 현재 개발도상국의 상당수 어린이들은 근거리에 학교가 없어서 교육을 받지 못하거나, 학교 를 다니더라도 교과서와 책걸상 - 조명 등이 없이 어두운 교실에서 맨바닥에 앉아 학습을 하는 등 어려움을 겪고 있다. 유네스코의 2008년 “모든 사람을 위한 교육'(EFA) 점검보고서2)에 따르면, 아 프리카의 6 개국(케냐 · 말라위 · 모잠비크 · 우간다 · 탄자니아 · 잠비아)의 6 학년 학생들 중 절반 이 상이 교과서가 전혀 없이 학교를 다니고 있으며 기타 아프리카 국가의 교사들 중 $25 \sim 40 \%$ 가 담당

1) youngchoi@krivet.re.kr

2) UNESCO(2008). "Education for all by 2015 : will we make it? EFA Global Monitoring Report." http://unesdoc. unesco.org/images/0015/001547/154743e.pdf 
교과의 교과서를 보유하지 못하고 있다고 한다. 또한 라틴아메리카 여러 나라의 초등학교 학생들 중 $1 / 3$ 만이 교과서를 소유하고 있다는 통계도 있다. 이처럼 열악한 교육환경에 처해 있는 최빈국과 저소득국가의 학생들은 심각한 교육기회의 차별을 겪고 있다.

이와 같은 문제를 해결하기 위해, 유네스코(UNESCO)는 유엔(United Nations, UN)의 '새천년 개 발 목표’ (Millennium Development Goals)중 하나인 ‘초등교육의 보편화’ (Universal Primary Education) 및 ‘성차별 해소’(Achievement of Gender Parity)의 달성을 위해 ‘모든 사람을 위한 교육'(Education For All)이라는 목표 아래 2000년부터 다양한 국제기구 및 세계 각국의 정부와 협력해서 어린이 · 청소년 · 성인들에게 양질의 교육을 제공하기 위한 다양한 노력을 기울이고 있 다. 유네스코의 '모든 사람을 위한 교육 점검 보고서’에 따르면 활발히 전개되고 있는 '교과서 보급 사업’ 은 ‘숙련되고 질 높은 교사’ · ‘효과적인 교수방법’과 함께 교육의 질을 향상시킬 수 있는 핵 심적 요소로 인식되고 있다.

호주 국제개발청의 보고서는 교사와 학교 - 교과서 등 교육자원의 부족이 학습의 효과를 향상시키 는 데 주요 장애가 되고 있다고 지적한다. 따라서 '교과서 보급' 사업은 '학교의 건설 및 시설 개 · 보수’사업과 함께 ‘모든 사람을 위한 교육’의 목표 달성에 있어 큰 역할을 담당하고 있다.

이와 같은 세계적 사업과 노력의 일환으로, 교육대외원조사업의 걸음마를 뗀 한국이 '라오스 중등 학교 교과서 보급 사업’을 완료했다. 또한 향후에도 추가적으로 개발도상국에 교과서를 공급할 계 획을 세우고 있다. 한국은 '라오스 중등학교 교과서 보급 사업’을 통해 라오스의 교육 여건 개선과 교육의 질적 향상에 기여하는 것을 목표로 삼았다. 또한 라오스의 인쇄기술 연수 및 인쇄기 보급, 교과서 인쇄 등을 통해 교과서 자체 공급 역량을 강화하도록 했다. 또한 라오스의 교육과정 개발 자 문 및 연수를 통해서 교육과정을 자체적으로 기획하고 개발하는 능력을 함양시키고자 노력하기도 하였다. 이는 근본적으로 라오스 정부에서 추진하고 있는 교육 목표 달성을 위한 인프라를 구축하 고자 하는 계획의 일환으로 추진되었다. 그 과정에서 시행착오도 있었지만 우리나라에 앞서 대외원 조사업을 시작한 해외 선진국들의 사례 학습을 통해 교과서 보급사업 역량을 축적하고 일정한 성과 를 낼 수 있었다.

본 글에서는 한국국제협력단(Korea International Cooperation Agency, KOICA)에서 시행한 '라 오스 중등학교 교과서 보급 사업’의 내용과 성과를 살펴보고, 향후 교과서 보급 사업을 추진할 경우 에 필요한 개선방안을 제시하고자 한다.

3) AusAID(2007). "Better Education: A Policy for Australian Development Assistance in Education." http://www. ausaid.gov.au/publications/pdf/education_policy.pdf 


\section{II. 라오스 교과서 보급사업 개요 및 성과}

\section{가. 라오스의 교육}

라오스 정부는 '모든 이를 위한 교육발전계획 2003-2015 (Education for All National Plan of Action 2003-2015)'를 발표하고, 교육개혁에 기초하여 빈곤을 감소시키고 인적자원을 능동적으로 개발하기 위한 노력을 기울이고 있다. 2008년 기준 라오스의 학생 수는 초등학생 890천명 - 중등학 생은 390천명 수준이며, 문자 해득률 $85.5 \%$ · 초등교육 이수율 $80.8 \%$ · 중학교 이수율 $48.3 \%$ 수 준에 머무르고 있는 실정이다. 2010년까지 문자 해득률 $90 \%$ - 초등학교 이수율 $92 \%$ - 중학교 이 수율 $63 \%$ 를 교육분야 개발지표로 설정하고 있다. 라오스의 교육은 초등학교 - 중등학교 - 각 분야 기술학교 · 대학교 · 기타 사교육 분야로 구성되어 있다. 교육환경 특히 교육 기자재 · 교과서 등의 보급 부족으로 효율적인 교육이 어려워 국가발전에 필요한 인적자원 양성에 어려움을 겪고 있다.

\section{1) 라오스 초· 중등 교육제도}

\section{가) 기본학제}

라오스의 현행 초, 중등 교육 기본 학제는 5-3-3제로, 초등학교(primary school) 5년(6-11세), 중학교(lower-secondary school) 3년(12-14세), 고등학교(upper secondary school) 3년으로 되어 있다. 초등이전의 교육으로 3년제 유치원 교육(3-5세)이 있으며, 중등학교 이후 교육(postsecondary school)은 1-2년, 대학수준 교육(tertiary education)은 3-7년에 걸쳐 이루어지고 있다. 초등학교 교육은 법적으로는 의무교육으로 되어 있다. 그러나 현실적으로는 초등학교에 다니지 못 하고 있는 아동들이 상당히 많다. 중등학교는 3년제 중학교와 3년제 고등학교가 있으며, 이외에 6 년제 중등학교(complete secondary school)도 있다. 현재 교사 운용의 효율성 등 여러 가지 교육 여건으로 인하여 3 년제 고등학교의 수는 급격히 감소하고 있으며 이와는 대조적으로 6 년제 중등학 교의 수는 급격히 증가하고 있다.

이러한 학제에서 보는 바와 같이 초 - 중등교육은 현재 11년으로 되어 있다. 그러나 이러한 학제는 대개 12 년으로 되어 있는 국제적 기준에도 맞지 않을 뿐 아니라 중등 및 대학 수준에서의 학생들의 학업성취 수준을 낮추는 결과를 초래한다는 인식하에 라오스 정부는 초 · 중등교육을 12 년으로 연 장하는 학제 개편을 진행하고 있는 중이다. 핵심 내용은 중학교 교육기간을 3 년에서 4년으로 1 년 연장함으로써 초 · 중등교육 전체 기간을 12년(5-4-3)으로 한다는 것이다. 새로 개정되는 이러한 학제는 2009년부터 단계적으로 개편하기 시작하여 2015년에 전체 학년에 실행할 예정으로 되어 있다. 


\section{나) 초·중등교육기본 현황}

\section{(1) 초등교육 기본 현황}

2004/5년도 라오스 교육부 통계 자료 ${ }^{4}$ 에 의하면 전국의 초등학교 수는 8,573 개이며 이 중 사립 학교는 105 개로 되어 있다. 전체 학생 수는 890,821 명이며 이 중 여학생 수는 409,593명이다. 한 편 전체 교원 수는 27,586 명이며 이 중 여교사 수는 12,656 명이다. 학년별 학생 수는 〈표2-1〉과 같다.

\section{〈표2-1〉 초등학교의 학년별 학생 수}

\begin{tabular}{|c|c|c|c|}
\hline & 학생 수 & 여학생 수 & 남학생 수 \\
\hline 학년 & 283,096 & 131,592 & 151,504 \\
\hline 1학년 & 189,101 & 87,093 & 102,008 \\
\hline 2학년 & 161,611 & 73,948 & 87,663 \\
\hline 3학년 & 138,258 & 62,725 & 75,533 \\
\hline 4학년 & 118,755 & 54,235 & 64,520 \\
\hline 5학년 & 890,821 & 409,593 & 481,228 \\
\hline 합계 & &
\end{tabular}

초등학교 취학률은 1990 년도에는 $63 \%$ 였다. 취학률은 그 후 여러 국제기관들 및 정부의 노력에 의 하여 2001년도에는 77\%까지 높아졌으며, 2006년도에는 85\% 수준에까지 이르렀다. 라오스에는 초등교육이 의무교육임에도 불구하고 완전 취학에 이르지 못하는 중요 원인은 지리적 이유에 있다. 라오스는 기본적으로 크고 작은 마을들로 이루어져 있는데 마을간 교통망이 연결되지 않은 곳들이 많다. 2005년도 조사에 의하면 전국의 10,522 개 마을 중에서 2,092 개 마을에는 아예 초등학교가 없으며, 4,704 개 마을에는 전체 학년이 다 있는 학교가 하나도 없다. 이 중 특히 가난한 지역에는 $70 \%$ 의 학교가 3 개 학년 이하의 학년만을 운영하고 있다.

라오스 초등학교의 특징 중의 하나는 위의 표에서 보는 바와 같이 1학년에서 2학년으로 올라가는 학생 수가 적다는 점이다. 이는 1학년에서의 탈락률이 대단히 높다는 뜻이다. 한 연구 $(2007)^{5)}$ 에 의 하면 초등학교 1학년에서의 탈락률은 약 30\%가 된다. 그리고 2학년에서의 탈락률도 $18-19 \%$ 정도 가 된다. 초등학교 입학 전 교육이 제대로 되지 않은 상태에서 입학하는 학생 수가 많기 때문이라고 한다. 그러나 이러한 탈락률은 1992년도 이후로 많이 낮아지고 있다고 한다.

초등학교 5년을 다 마치고 졸업하는 학생들의 비율은 1997 년도의 경우 여학생은 약 $50 \%$, 남학생 은 약 $58 \%$ 였는데 2006년에는 각각 $66 \%, 73 \%$ 로 향상되었다고 한다. 그러나 이들 졸업생의 학업성 취수준은 매우 낮다고 한다. 2001년도 조사에 의하면 초등학교 졸업생들의 약 48\%만이 '기초문해'

4) Ministry of Education, LaoPeople's Democratic Republic, "Annual Bulletin, 2004-2005,"

5) LAO PDR(2007). "Sector-wide approachin education sector development, Interim Report(Draft)." 
수준에 도달했으며, $52 \%$ 정도는 실질적으로 거의 기능 문해 수준에 도달하지 못했다고 보고하고 있다. 이 조사에 의하면 성인 문해율이 $68 \%$ 정도로 나왔다.

(2) 중등교육 기본 현황

$2005 / 6$ 년도 자료에 의하면 라오스의 중학교수는 642 개, 고등학교 수는 28 개, 중고를 통합한 학교 의 수는 310 개로서 총 980 개에 달하고 있다. 한편 학급 수는 중학교 5,306 학급, 고등학교 2,752 학급으로서 총 8,058 학급이다.

교사 수는 총 15,132 명으로서 남교사 8,605 명, 여교사 6,527 명이다. 학생 수는 중학교(6-8학년) 243,131 명, 고등학교(9-11) 147,510명으로서 총 390,641명이다. 이러한 숫자는 중학생의 경우 동일 나이 집단 인구수의 $51.7 \%$ 에 해당하며, 고등학생의 경우 $34.5 \%$ 에 해당된다. 즉, 중학교의 취 학률은 약 $52 \%$, 고등학교의 취학률은 약 $35 \%$ 정도라고 할 수 있다. 여학생 수는 전체의 약 $43 \%$ 에 달한다. 라오스 중등학교의 학년별 학생 수는 〈표2-2〉와 같다.

\section{〈표2-2〉 중등학교의 학년 별 학생 수}

\begin{tabular}{|c|c|c|c|c|}
\hline 학년 & 학생 수 & 여학생 수 & 남학생 수 & \multirow{2}{*}{ 합계 } \\
\hline 6학년(중1) & 94,232 & 41,240 & 52,992 & \multirow{2}{*}{131} \\
\cline { 1 - 3 } 7학년(중2) & 78,189 & 34,292 & 43,897 & \multirow{2}{*}{147,510} \\
\hline 8학년(중3) & 70,710 & 30,556 & 40,154 & \\
\hline 9학년(고1) & 56,712 & 24,139 & 32,573 & \\
\hline 10학년(고2) & 47,967 & 20,538 & 27,429 & 390,641 \\
\hline 11학년(고3) & 42,831 & 17,792 & 25,039 & \\
\hline 합계 & 390,641 & 168,557 & 222,084 & \\
\hline
\end{tabular}

위 표에서 보는 바와 같이 중 1 에서 중 2 로의 이전 단계에서 학생들의 수가 많이 감소하며, 이러한 현상은 고1에서 고2로의 이전 단계에서도 나타나고 있다. 또한 중학교에서 고등학교로의 진학 시 에도 상당수의 학생들이 진학하지 않음을 알 수 있다. 이러한 상황에도 불구하고 전체적으로 최근 중등수준의 취학률은 빠른 증가세를 보이고 있다. 그 결과 중등학교의 경우 학급당 학생 수가 급격 히 증가하고 있으며, 초등 교원에서 중등 교원으로의 이전 비율이 증가하고 있다.

6) 이 부분은 코이카 업무자료(2007), "라오스중등학교 교과서 보급사업 실시협의 결과보고서" 10 쪽의 내용을 재구성한 것 이다. 


\section{나. 라오스의 교과서 보급 실태}

라오스 정부는 교과서의 중요성을 인식하여 각급 학교에 보급계획을 세우고는 있으나, 국가재정이 열악하여 보급하지 못하고 있는 실정이다. 따라서 라오스 정부는 전국의 중등학교에 교과서를 보 급하여 기초교육 향상 및 인적자원 양성을 도모하고 '새천년 개발 목표'(millenium Development Goals, MDGs) 달성을 이루고자 지원 사업을 요청하였다. 또한 세계화의 영향으로 교육내용 및 환 경이 급변하고 있는데 반해 우수한 자원을 양성해야 하는 교사들 역시 필요한 기본교재가 제공되지 않아 현실적으로 기초적인 교육이 이루어지지 않고 있다.

초등학교 교과서 보급은 라오스 정부 및 국제사회의 지원으로 점차 개선되고 있으나, 중등학교의 교과서 보급은 매우 열악한 상황이므로 이에 대한 지원 필요성이 높다. 현재 초등학교 교과서 보급 률은 약 $80 \%$ 이나, 중등학교 보급률은 약 $20 \%$ 에 그치고 있다.

\section{다. 교과서 보급사업 개요}

우리나라 정부는 $\mathrm{KOICA}$ 를 통해 라오스의 중등학교에 교과서를 공급하기로 결정을 하였다. 본 사 업은 2007-2009년의 3년 동안 3백만불을 무상으로 원조하여, 라오스 전체 중등학교 학생 및 교사 용 교과서를 인쇄하여 주는 것이다. 사업의 주요 목적은 교과서 보급 및 교육과정 개발 자문 등을 통한 교육여건 개선으로 교육의 질적 향상에 기여하고자 함이다. 상세 내용은 다음의 〈표2-3〉에서 설명하고 있다. 
〈표2-3〉라오스 중등학교 교과서 보급사업 개요

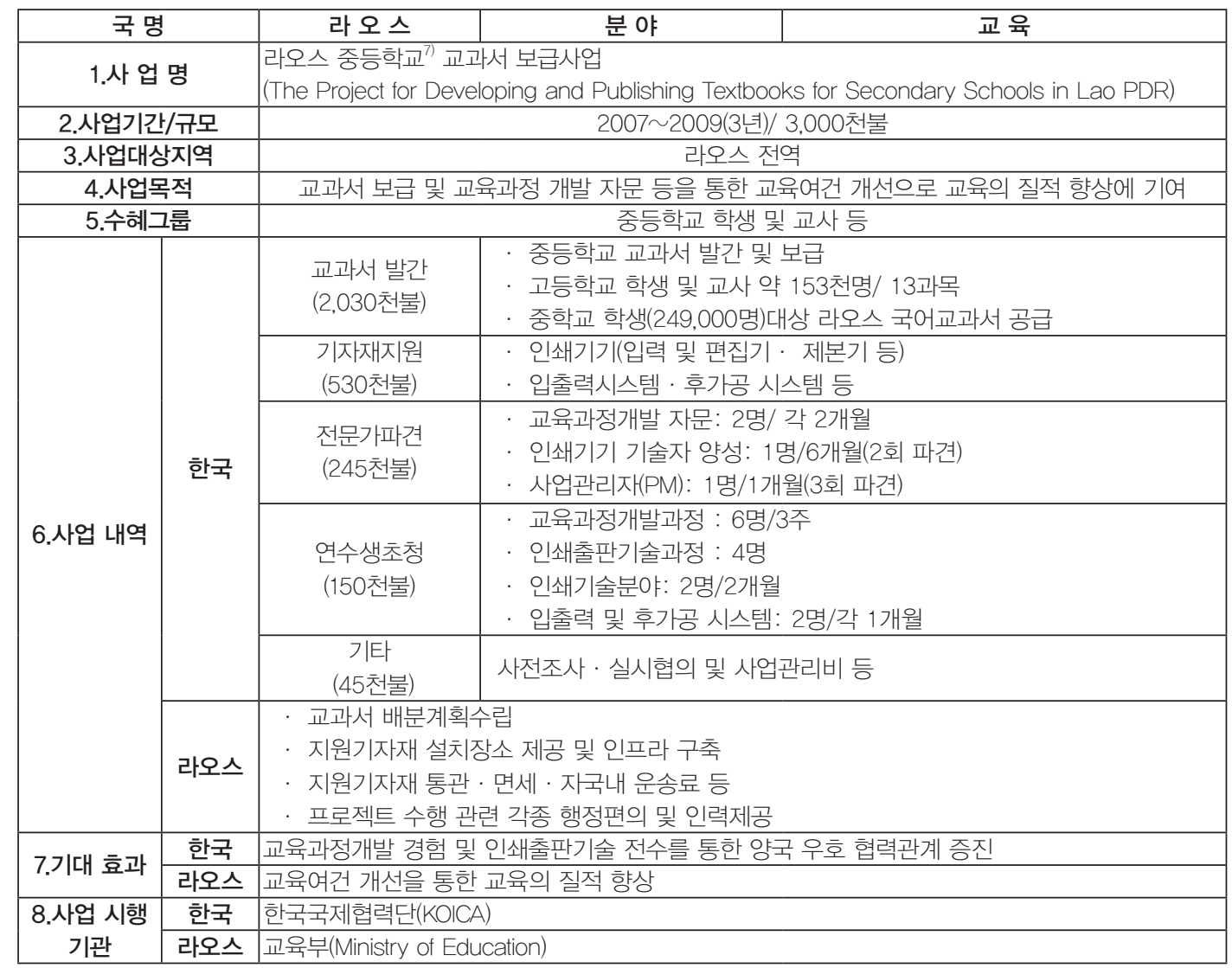

\section{라. 라오스 중등학교 교과서 보급사업의 성과}

\section{1) 교과서 제공}

본 사업에서 일반 중고등학교 교과서 총 $2,661,820$ 권을 인쇄하여 보급하였다. 구체적으로 고등학 교 13종 전체(외국어 2종류 중 영어만) 2,363,540과 중학교 1 3학년 라오어 전체 298,280권을 보급하였다. 그 결과 라오스의 모든 고등학생들이 각자 개인별로 전 과목 교과서를 한 세트씩 보유 하게 되었고, 모든 중학교 학생들이 라오스 국어 교과서를 보유할 수 있게 되었다.

이처럼 라오스의 중등학교 학생들이 교과서를 보유함에 따라 라오스 교육의 질이 향상되었고, 자신 들이 공부하는 교과서가 대한민국이 공급했다는 사실을 학생들이 인식함에 따라 우리나라에 대한 호감도 및 태도에 있어 긍정적인 측면을 기대할 수 있게 되었다.

7) 중등학교는 중학교와 고등학교를 총칭하는 용어이다. 


\section{2) 교육과정 개발 자문}

또한 라오스의 교육과정 개발능력을 향상시킬 수 있었다. 교육과정 개발 총론 및 각론(수학 및 과 학) 전문가를 파견하여 현지에서 해당 전문가를 교육시키고, 교육과정개발 전문가를 우리나라로 초 청하여 연수를 시킴으로써 현지 및 국내 연수를 병행하여 그 효과를 극대화하고 라오스의 전문가들 의 교육과정 개발 능력을 향상시켰다.

가) 주요 교육내용

〈표2-4〉 교육과정 개발 자문 주요 교육내용

\begin{tabular}{|c|c|}
\hline 주요 교육내용 & \\
\hline 국가 교육과정 개발을 위한 절차 & $\begin{array}{l}\cdot \text { 현행교육과정의 문제점 분석 } \\
\cdot \text { 현행교육과정 개정에 대한 요구 분석 } \\
\cdot \text { 시대, 사회, 학문의 변화 추세 분석 } \\
\cdot \text { 외국의 교육과정 개혁 동향 분석 } \\
\cdot \text { 이를 바탕으로 한 개정의 기본 방향, 원칙, 방향 설정 } \\
\cdot \text { 인간상, 편제, 교수-학습 지도지침, 평가 지침 개발 } \\
\cdot \text { 초안에 대한 전문가 그룹의 심층 검토, 수정, 보완 } \\
\cdot \text { 현장적합성검토, 공청회, 심의회를 통한 최종 점검 } \\
\cdot \text { 개정안확정, 고시 } \\
\cdot \text { 교과서개발 } \\
\text { · 교육과정/교과서 적용 }\end{array}$ \\
\hline 한국의 교육과정 개발 & $\begin{array}{l}\cdot \text { 해방이후 현재까지의 개발 방식 개요 소개 } \\
\cdot \text { 수시개정 방식의 소개 } \\
\text { · 총론각론의 구조 소개 } \\
\text { · 교육부, 연구소, 단위 학교와의 관계 } \\
\text { · 한국의 학제, 학교 제도 소개 } \\
\cdot \text { 한국의 교육과정 개발 절차 } \\
\cdot \text { 한국 교육과정의 문제점 } \\
\cdot \text { 한국교육과정평가원 소개 }\end{array}$ \\
\hline 교육과정 세부 내용개발 방법 & $\begin{array}{l}\text { 교육목표의 설정 방법 } \\
\cdot \text { 교육목표의 진술 방식 } \\
\cdot \text { 교육내용의 설정 및 조직 방식 } \\
\cdot \text { 교육평가의 종류와 고려 방식 } \\
\cdot \text { 교육내용 양의 적합성 분석 } \\
\cdot \text { 교육내용 난이도의 적합성 분석 } \\
\cdot \text { 교과 간 내용의 중복성과 계열성 문제 분석 } \\
\cdot \text { 교과의 통합과 분화의 문제 분석 }\end{array}$ \\
\hline 학업성취평가 방식 & $\begin{array}{l}\cdot \text { 상대평가와 절대평가 } \\
\cdot \text { 객관식 평가와 주관식 평가 } \\
\cdot \text { 학업성취 국제비교 평가 } \\
\cdot \text { 수행평가와 기관평가 }\end{array}$ \\
\hline $\begin{array}{c}\text { 라오스 국가 교육과정 질 향상을 } \\
\text { 위한 제언 }\end{array}$ & $\begin{array}{l}\text { ·교육과정개정 절차 및 개정 방식의 개선을 위한 제언 } \\
\text { · 현재 개정되고 있는 교육과정 세부 내용의 개선을 위한 제언 } \\
\cdot \text { 교과별 교육과정 문서 및 개발 체제 개선을 위한 제언 } \\
\text { · 교육과정개발 연구기관의 발전을 위한 제언 }\end{array}$ \\
\hline
\end{tabular}




\section{나) 교육과정 개발(정)과정 및 방식}

(1) 새 교육과정의 적용 계획

새로 개정된 교육과정이 언제부터 어떻게 현장에 적용될 것인가는 새 교육과정에 따른 새 교과서가 언제까지 개발, 인쇄될 것인가에 달려 있다. 2008년 1월 기준 라오스의 교육부와 교육연구원의 교 육과정 및 교과서의 개발, 인쇄, 보급 일정 계획에 따른 현장 적용계획은 다음과 같다.

\section{(가) 초등학교 ${ }^{8)}$}

초등학교 1-2학년의 경우 08년 8월까지 교과서의 인쇄 및 현장에의 보급이 완료될 계획이다. 그리 고 새 교과서 사용에 대한 교사들의 연수도 8월중에 시행될 예정이다. 그러면 새 학년도가 시작되 는 08년 9월부터는 새 교육과정이 적용될 것으로 예상된다. 3-4학년의 경우, 09년 8월까지 교과 서가 인쇄되고 보급이 완료될 예정이다. 따라서 09년 9월부터 새 교육과정이 적용될 것이다. 초등 학교의 최종 학년인 5 학년의 경우, “ 10 년 2 월까지 교과서가 인쇄, 보급될 예정임으로 새 학년도가 시작되는 2010년 9월부터는 확실하게 적용될 것으로 예상된다.

\section{(나) 중등학교}

3년제에서 4년제로 개편되는 중학교의 전 학년 교육과정은 2008년 말이나 2009년 초에 완성될 예 정이다. 새 교육과정에 따른 교과서의 인쇄 및 보급은 중학교 1학년의 경우 교과서가 2009년 8월 중에 완료되어 2009학년도가 시작되는 9월부터는 현장에 새롭게 적용되기 시작할 것이다. 중학교 2학년의 경우 2010년 8월에 교과서가 인쇄, 보급되며 따라서 2010년 9월부터 적용될 것이며 중3 은 2011년, 그리고 중4는 2012년부터 현장에서 적용되기 시작할 것이다. 고등학교의 경우는 2013 년도부터 점진적으로 적용되기 시작하여 2015년에는 전체 고등학교에 새 교육과정과 교과서가 적 용될 것이다. 따라서 2015년에는 전국의 초, 중, 고등학교 학생 모두가 새 학제 개편에 따른 새 교 육과정과 교과서 체제하에서 수업을 받게 되는 첫 해가 될 것이다.

이러한 교육과정총론 자문에 이어, 국가 수준의 교육과정과 라오스 각 주 정부에 대한교육과정 편 성 · 운영 지침, 수학 · 과학의 학교 교육과정 편성 · 운영에 관한 수학 · 과학의 교육과정 개발 자료 를 조사·분석하고, 이를 바탕으로, 라오스의 실정에 알맞은 학교 수학 · 과학 중등학교 교육과정을 편성 · 운영할 수 있도록 자문하였다.

8) 초등학교 1-2학년의 경우 2008년 8월까지 교과서가 인쇄, 현장에 보급되고 이에 대한 교사 연수도 다 완료될 것으로 계 획되어 있기 때문에 2008년도 9월부터 현장 적용에 들어갈 것으로 충분히 예상된다. 그러나 이 점에 대해서 필자는 현 지의 연구자들에게 직접 확인하지는 못하였다. 따라서 초등학교의 경우 2008년도부터 적용이 되는지 아니면 중학교 1 학년이 새롭게 적용되는 2009년도에 동시에 적용되는지는 앞으로 확인할 사항이다. 
마지막으로 라오스의 교과서 인쇄 역량을 증대시켰다. 라오스 국정교과서에 모든 교과서를 인쇄하 도록 하였으며 이를 위해 필요한 접지기, 재단기, 코팅기, 제책기 등을 제공하였다. 또한 인쇄기술 자의 현지 및 국내 연수를 통해 인쇄능력향상에 기여하였다.

\section{III. 주요 선진국 및 국제기구의 교과서 보급사업}

\section{가. 교과서 사업의 의의와 중요성}

2008년에 발간된 유네스코의 '모든 이를 위한 교육'(Education For All, EFA) 점검 보고서'에 따 르면, '교과서 보급’은 '숙련되고 질 높은 교사' · ‘효과적인 교수방법’과 함께 교육의 질을 향상시 킬 수 있는 핵심적 요소로 인식되고 있다. 그 내용은 다음과 같다.

첫째, 학생들이 '무엇을' '얼마나' 학습할 수 있는지, 그 교육적 효과를 결정함에 있어서 교과서가 교사와 교수방법에 못지않은 큰 영향력을 발휘한다. 학습은 학생과 교과서의 상호작용에 의해 이루 어지는 부분이 크다.

둘째, 소득이 현저히 낮은 환경의 학생들에게는 교과서를 제공하는 것만으로도 사회경제적인 지위 에 따른 불이익을 상당부분 상쇄시키는 효과를 볼 수 있다. 몇몇의 비교 연구들은 특별히 저소득층 가정의 학생들의 경우에, 교실에 교과서가 비치되어 있을 때 이들이 시험에서 더 좋은 성적을 거둔 다는 연구결과 ${ }^{10}$ 를 발표했다.

이러한 이유로 세계은행(World Bank) · 유니세프 · 유네스코 등의 국제기구들이 선진국 정부로부 터 제공받는 원조자금을 바탕으로 전개해온 대 개도국 교육 사업에 '교과서의 개발과 보급을 위한 재정적·기술적 원조'가 항상 포함된다.

개발도상국 학생들이 처해 있는 교육환경은 선진국과 비교도 할 수 없을 만큼 열악한 상황이다. 아 래에서 제시된 통계수치는 유네스코 2008년 '모든 사람을 위한 교육'(EFA) 점검보고서 ${ }^{11)}$ 에서 발췌 한 것이다.

- 아프리카의 6 개국(케냐 - 말라위 · 모잠비크 - 우간다 · 탄자니아 - 잠비아)의 6학년 학생들 중 절반 이상이 교과서가 전혀 없이 학교를 다니고 있다.

- 위에서 제시된 6 개국을 포함한 기타 다른 아프리카 국가들의 교사들 중 $25 \%$ 에서 $40 \%$ 가 담

9) UNESCO(2008). "Education for all by 2015: will we make it? EFA Global Monitoring Report." http://unesdoc. unesco.org/images/0015/001547/154743e.pdf

10) Fuller and Clarke, 1994; Heyneman and Jamison, 1980; Lockheed and Hanushek, 1988, UNESCO 2008 보고서 p.73에서 인용.

11) UNESCO(2008). "Education for all by 2015: will we make it? EFA Global Monitoring Report." http://unesdoc. unesco.org/images/0015/001547/154743e.pdf 
당 교과목의 교과서가 없다.

· 볼리비아 - 브라질 · 칠레 · 콜럼비아 - 에콰도르 · 파나마 - 페루 · 베네수엘라의 초등학생들 중 오직 $1 / 3$ 만이 교과서를 소유하고 있다.

- 많은 개발도상국에서 오로지 교사만이 교과서를 소유하고 있으며, 학생들은 수업시간의 대 부분을 칠판에 교사가 적는 교과서 내용을 옮겨 적는데 소비하고 있다. 라이베리아(Liberia) 교육부가 제시한 통계에 따르면, 초등학교의 경우 학생 대 교과서의 비율이 공립학교는 $27: 1$, 사립학교는 $20: 1$, 기독교학교는 $15: 1$ 이다.

이처럼 열악한 교육환경에 처해 있는 최빈국과 저소득국가의 학생들은 ‘빈곤’에 더해 ‘성별’과 ‘피 부색' · ‘계급’ 등에 의해 심각한 교육기회의 차별을 겪고 있다. 따라서 교과서 보급 사업은 개발도 상국의 아이들이 UN 인권선언문에 기재된 '인간으로서의 교육 받을 권리를 보장받을 수 있도록 도 움을 제공한다' 는 점만으로도 의미가 있다고 할 수 있다. 이에 더해 교과서의 보급은 최빈국 및 저 소득 국가의 어린이들에게 보다 높은 질의 교육을 제공함으로써 향상된 삶을 향한 희망적인 좌표를 제시한다는 점에서 더욱 뜻깊다 할 수 있다.

\section{나. 선진국의 사례}

\section{1) 호주의 교육 원조사업}

\section{가) 호주국제개발청(AusAID)}

호주정부는 호주국제개발청(Australian Aid for International Development, AusAID)을 통해 지난 40년여 년에 걸쳐 태평양 연안의 아시아 국가들을 중점 지원 대상으로 하여 - 아프리카와 중 동 - 중앙아시아 일부 국가들을 포함 - 원조를 제공해오고 있다. 호주의 주된 원조대상국가들은 파 푸아 뉴기니 · 인도네시아 · 베트남 · 동티모르 · 필리핀 · 솔로몬제도 등이다. ${ }^{12)}$ 이들 수원국가들 은 소득에 따른 국가분류에서 주로 최빈국 (Least Developed Country) 혹은 저소득 국가 (Lowincome country)로 분류된다. ${ }^{13)}$

호주국제개발청 역시 '새천년 개발 목표' (millenium Development Goals, MDGs)와 '모든 사람 을 위한 교육'(Education For All, EFA)을 기본 틀로 하여, 다양한 국제기구들과 공조 하에 원조 를 제공하고 있다. AusAID의 연차 보고서에 따르면, 매년 호주정부의 공적개발원조금 중 약 $15 \%$ 안팎의 자금이 교육 사업에 지원되고 있다. 호주는 2007년 2008년 ‘모든 사람을 위한 교육’사업 의 이사회 국가이자 지원국으로서 베냉(Benin) · 캄보디아(Cambodia) · 말리(Mali) · 모리타니아

12) AusAID(2006). "Statistical summary 2004-2005: Australia's international development cooperation." http:// www.ausaid.gov.au/publications/green-book/green_book_0405.pdf.

13) AusAID(2006). "Statistical Summary 2004-2005," 
(Mauritania) · 몽골(Mongolia) · 모잠비크(Mozambique · 시에라리온(Sierra Leone)의 7개 국가 에 ‘초등교육의 보편화’ (universal primary education)를 위해 249만불(USD)을 제공했다. ${ }^{14)}$ 호주국제개발청은 세계은행(World Bank) · 아시아개발은행 (Asian Development Bank) · 세계 식량계획 (World Food Program) · 유니세프(UNICEF) 및 에이즈·결핵 · 말라리아와 퇴치를 위 한 국제펀드(Global Fund to Fight AIDS, Tuberculosis and Malaria) 등과 원조협력을 하고 있 다. ${ }^{15)}$

\section{나) 호주국제개발청의 교육원조사업}

호주정부의 공적개발원조사업이 시작된 이래 지난 40여 년에 걸쳐 현재 호주정부가 펼치고 있는 주 요 교육원조사업들의 구체적 내용은 아래와 같이 요약될 수 있다. ${ }^{16)}$

· 초 · 중고등학교 교사들을 위한 연수 제공 및 교재교구의 공급

· 교육과정 개발 지원

· 초 · 중등학교 건설 및 학교 시설 개· 보수

· 교과서 인쇄 및 배분 사업

· 각 학교에 수도 및 위생시설 건설 사업

· 직업 교육 및 훈련 관련 사업: 직업 교육 및 훈련의 질 제고를 위해 수원국가에 담당 부서 를 설립하거나 현지 $\mathrm{NGO}$ 들과의 협력을 통해 직업훈련 연수 제공

- 장학금 제공 사업: 각 국가의 교육 공무원 및 학자들에게 호주 대학으로의 연수를 위한 장학 금을 지급하거나 혹은 수원국 학생들의 국내학교 진학을 위한 장학금 제공

- 원격대학(distance education of tertiary level) 제공 사업: 개도국 학생들이 자국 내에서 호주의 대학교육을 받을 수 있도록 원거리 교육을 위한 시설 마련

· 교사 이직률을 낮추기 위해 교사 월급 인상 및 사범대학의 시설 개선

최근 들어 '새천년 개발목표' 달성을 위한 '모든 사람을 위한 교육(EFA)'사업 목표에 집중하면서 AusAID의 교육원조사업은 주로 학교건설 · 교과서 인쇄 및 배분 · 위생시설의 공급 · 교사 연수 등 을 중심으로 이루어지는 경향을 보인다.

호주 국제개발청의 교육원조사업은 크게 '양질의 교육에 대한 접근성 향상' (higher access

14) AusAID(2008). "Education Annual Thematic Performance Report 2007-2008."http://www.ausaid.gov.au/ publications/pdf/atpr_education_0708.pdf

15) AusAID(2006). "Statistical Summary 2004-2005,"

16) AusAID(2009). "Annual Reports(1999-2008)." http://www.ausaid.gov.au/publications/pubout.cfm?ID=8691_58 77_871_8496_1205\&CFID=3328295\&CFTOKEN=90652321 
of more children to better education)과 '보다 철저하고 효과적인 교육 관리 체계의 정립” (improved governance of national education system)이라는 두 가지 목표를 지향하고 있다. 학 교나 관련 시설을 건설해주고 교과서를 무료로 배분해주는 사업 등은 전자를 달성하기 위함이며, 원조국가들이 체계적인 교육제도를 구축할 수 있도록 교육과정 개발 - 개정을 지원하고 고위 교육 공무원에게 해외연수를 제공하는 등의 도움은 후자를 달성하기 위함이다. 실제적으로 모든 어린이 들이 교육을 받을 수 있기 위해서는 학교의 건설과 교과서 및 교사를 확보하여 제공하는 것이 필요 하겠으나, 장기적으로 '양질’의 교육이 제공되도록 하기 위해서는 교육관리체계의 효과적 운영 또 한 이에 못지않게 중요하다. 따라서, 이 두 가지 목적의 사업들은 상호보완적으로 함께 진행되어야 하며, 이러한 맥락에서 호주 국제개발청의 포괄적 교육사업 접근 방식은 바람직하다 할 수 있다.

\section{2) 일본의 교육 원조사업}

\section{가) 일본국제협력기구(JICA)}

일본의 대외원조사업은 주로 '자이카'(Japanese International Cooperation Agency, JICA)'로 알려진 '일본국제협력기구’를 통해 이루어진다. 일본국제협력기구(JICA)는 지난 50여 년에 걸쳐서 세계 각지의 정부 및 다양한 국제기구들과의 공조 하에 원조기금 및 차관을 제공하거나 자원봉사단 을 파견하는 등의 사업을 시행하고 있다. 90 년대 초에 전체 원조예산의 $12 \%$ 정도에 이르는 150 억 엔을 교육사업에 투자했으며, 매년 점차적으로 그 투자액을 증가시켜 현재는 전체예산의 약 $20 \%$ 에 이르는 250 억 엔을 교육원조사업에 투자하고 있다. 일본국제협력기구의 교육원조사업은 호주 국제 개발청(AusAID)와 동일하게 '새 천년 개발 목표'와 '모든 사람을 위한 교육' 목표 달성이라는 청사 진을 바탕으로 진행되고 있다. 


\section{나) 일본국제협력기구의 교육 원조사업}

일본국제협력기구의 교육 원조사업은 ‘인적자원개발'이라는 큰 틀 안에서 ‘사회보장사업’(장애인 고용 및 지원 사업 등) · 건강사업’ (각종 질병 예방 및 치료 등)과 맞물려 진행되어오고 있다. 교육 원조사업은 크게 '기초교육'과 '고등교육' · '기술 - 직업교육 및 훈련'의 세 분야로 이루어지는데, 기초교육은 유치원부터 중학교까지를 포함하며 사회에서 인간답게 살아가기 위해 필요한 기본적인 지식과 기술 (문해력 등)을 획득하도록 하는 것을 목표로 한다. 반면 '고등교육'과 '직업교육 및 훈 련’은 경제발전을 위한 인적자원을 개발해 빈곤을 감소시켜 나가는 것을 그 목표로 한다. 구체적인 교육원조사업의 내용을 살펴보면 다음과 같다.

· 초·중고등학교 예비 및 현직 교사들을 위한 연수 제공

· 교과서 개발 및 배분 사업

· 교재교구 및 교사 지도서 개발 및 공급

· 초 · 중등학교 건설 및 학교 시설의 개 · 보수

· 각 학교에 수도 및 위생시설 건설 사업

· 지역사회 참여 캠페인

· 직업 교육 및 훈련 관련 사업

· 고등교육기관 지원 사업

· 해외협력봉사단(Japan Overseas Cooperation Volunteers, JOVC) 파견

일본국제협력기구의 교육원조사업의 내용은 호주의 그것과 크게 다르지 않다. 일본의 교육원조사 업 역시 교과서 · 교실 환경 · 교사 · 교육체제의 운영과 관리 등 학습에 영향을 미치는 다양한 요소 들을 개선하는 것을 목표로 사업을 포괄적으로 실시해오고 있다.

\section{3) 유네스코(UNESCO)의 이라크교과서 보급사업 ${ }^{18)}$}

유네스코는 지난 수십 년에 걸쳐서 세계 각국에 교과서를 무료로 보급하고 있다. 다음은 유네스코 가 이라크 교육부와의 협력 하에 실시한 교과서 보급사업의 구체적 내용이다.

17) JICA(2008). "Annual Reports (2001-2007)." http://www.jica.go.jp/english/publications/reports/annual/archive. $\mathrm{html}$

18) UNESCO(2005a). "Textbook quality improvement program: support to basic education in Iraq." http://unesdoc. unesco.org/images/0013/001394/139428e.pdf 


\section{가) 사업의 개요}

전쟁 후 이라크의 기초교육(Basic Education)을 재건하기 위해 실시된 이 사업은 유네스코가 미국 의 국제개발청(USAID)로부터 자금을 지원받아 2003년 5월부터 2005년 3월까지 이라크 교육부와 의 협력 하에 진행하였다.

이 사업은 '교과서의 질 향상시키기 프로그램(Textbook Quality Improvement Program)'이라는 이름으로 진행되었는데, 이라크에 있는 모든 초 - 중등학교 학생들에게 정치적으로 중립적이고 모 든 편견으로부터 자유로운 '수학'과 '과학' 교과서 5 백만 부를 보급하는 것이 사업의 주요한 목적 이었다.

\section{나) 사업의 내용}

이 사업은 크게 ‘교과서 인쇄’에 대한 전반적 과정과 ‘역량 강화’를 위한 과정의 두 부분으로 나 누어 살펴볼 수 있다. '교과서 인쇄'과정은'기존 교과서 내용의 검토(review)' ·'개정 교과서 인 쇄(printing)' · '새 교과서 보급(distribution)'을 포함하며, '역량강화’에 관한 과정은 '교육부 인사들을 위한 연수' 및 '교과서 보급을 위한 기반시설의 개선' 등과 같은 '역량 개발(capacity development)'관련 내용을 포함한다.

\section{(1) 교과서 인쇄 및 운송}

\section{(가) 검토 및 개정}

해외의 전문가들로 구성된 '자문단' International Textbook Advisory Team) - 이라크 자국 '교 과서자문위원회'(Iraqi Textbook Advisory Council) · ‘삼자승인위원회'(tripartite approval committee)로 구성된 '교과서 검토 위원단'(A review panel)을 구성하여 총 48종의 아랍어로 쓰 여진 초 - 중등학교 수학과 과학 교과서의 내용을 검토하였다. 시간적 제약으로 포괄적이고 획기적 인 내용 변화와 수정은 장기적 관점에서 서서히 진행하기로 합의하고 이번 개정 과정은 각종 편견 을 심어줄 수 있는 요소를 제거하는데 초점을 맞추었다.

\section{(나) 인 쇄}

이라크 내 인쇄소 및 인쇄기계에 대한 예비조사를 실시하여, 전체 인쇄소와 기계의 수 및 인쇄능력을 파악한 후에 실제로 인쇄소를 방문하여 예비조사의 내용과 일치하는지를 확인하고, 인쇄능력을 갖춘 인쇄소 30 군데를 대상으로 사업에 대한 공개입찰을 실시하여 교과서 인쇄가격을 하락시켰다. 인쇄기 의 성능 확인 결과 전체 인쇄량의 $76 \%$ 를 바그다드에서 인쇄할 수 있을 것으로 추산하였다. 최종적으 로 875만 부의 수학과 과학 교과서를 인쇄하였는데, 이 중 3/4은 이라크 내에서 인쇄하였다. 
(2) 업무능력의 향상

\section{(가) 업무관련 연수의 제공}

첫째, 교과서 전반에 관한 연수를 제공하였다. 교육에 있어서 교과서의 중요성 및 가치· 교육과정 개정과 맞물려 새로운 교과서의 개발 필요성 - 다양한 이미지 사용의 교육적 효과와 교과서에 나타 난 각종 편견에 관한 강의를 교과서 개정에 참여할 자문단원 (교사 - 학교장 · 수 · 과학 교육 전문 가 등)에게 제공하였다.

둘째, 교과서 인쇄 및 점검과 보급에 관한 연수를 제공하였다. 양질의 교과서를 생산하기 위해서는 모니터링팀(a monitoring team)의 역할이 중요하기 때문에, 교육부 직원 9명을 대상으로 교과서 스캐닝 후 작업과 최종 인쇄 직전 인쇄필름을 점검하도록 하였다. 인쇄가 시작된 후에는 각자 특정 인쇄기를 배당 받아 인쇄과정을 점검하는 등의 실제적 인쇄과정 점검에 관한 업무 연수를 제공하였 다. 또한 교육부 직원 14 명을 대상으로 창고의 재고 확인과 영수증 발행 및 교과서 운송 - 보급의 각 단계에 대한 전반적 이해 증진을 위한 연수를 제공하였다.

셋째, 컴퓨터 기초기술과 전산화된 교과서의 저장과 운송 시스템에 관한 연수를 제공하였다. 이라 크의 각 지역 행정구로부터 교과서 배급 및 관리에 관여하는 교육부 직원 2 명씩을 선발하여, 인터 넷과 이메일 사용하는 법 · 워드문서와 엑셀 프로그램 사용법 등 컴퓨터의 기본적 기능 사용법과 교 과서를 보관하고 보급하는데 사용되는 '재고조사데이터베이스시스템'(inventory control database system)을 사용하는 방법을 강의하였다.

\section{(나) 교과서 배급 체계와 구조의 개선}

첫째, 교육부와 각 지역 교육위원회 및 교과서 창고의 전산화를 추진하였다. 각 지역 교육위원회 간 의사소통을 활성화시키고 일의 능률을 향상시키기 위해 유네스코와 이라크 교육부가 함께 공개입 찰을 통해서 136 대의 컴퓨터와 각종 프로그램을 구입하여 교육부 - 각 지역 교육위원회 및 교과서 창고에 컴퓨터를 제공하였다.

둘째, 위성통신설비(Satellite communications facilities)를 제공하였다. 이라크 전 지역에 있는 교과서 보관소 간의 의사소통상의 어려움을 극복하고자 각 행정구역과 이라크 교육부에 설치할 총 22대의 위성통신설비를 구매하여 제공하였다.

(3) 해외연수

\section{(가) 교과서 내용 개발·개정 해외 연수}

교과서 내용 선정 및 개발 측면에서 성공적 사례를 배우기 위해 총 7 명의 이라크 교육부 고위 관리 들이 '모로코'와 '태국'으로 연수를 다녀왔다. 연수의 과정에서 각 국에 위치한 UNESCO 위원회 
의 활동 - 국가교육과정과 교과서 내용 개발 및 개정 과정에 대한 강의를 통해 교육개혁과 분권화 (decentralization)의 틀 안에서 이라크 교과서 내용을 개정하고 개발하기 위한 유용한 정보를 교 육할 수 있었다.

\section{(나) 교과서 생산 및 운송 해외 연수}

이라크 교육부 직원과 각 지역구에서 온 교과서 공급 담당자 총 21 명이 이집트를 방문해 교과서의 인쇄 및 보관을 위한 컴퓨터 작업과 위성 통신 장비를 통한 이점 등을 생생히 보고 듣고 이해하는 배움의 기회를 가질 수 있었다.

\section{(다) 사업의 성과}

- 이라크 교과서 개정 자문위원단을 대상으로 교과서 개정에 대한 초기 연수 제공 및 교과서의 품 질의 중요성에 대한 의식을 심어주었다.

· 대략 900만부의 수학과 과학 교과서를 인쇄 및 배분하였다.

· 이라크의 총 14,000 개 초 · 중등학교에 교과서를 배송하였다.

- 위성통신장비의 제공 등 이라크의 모든 지역 교과서 배급소의 컴퓨터화를 통해 교과서 배분구조 를 향상시켰다.

· 이라크 교육부 직원들의 직무 연수 및 특별연수를 통해 역량을 계발하였다.

\section{N. 향후 교과서 보급사업 추진 방향}

라오스 중등학교 교과서 보급 사업은 2007년부터 약 2년간 인쇄 기기의 제공 및 관련 연수· 교육 과정개발 총론 및 각론에 대한 자문 제공 - 교육과정개발 연수생 초청을 통해 교과서 부족 실태가 심각한 라오스 중 · 고등학교 교육여건을 개선시키고 장기적으로 라오스 교육의 질을 개선시켜 나 갈 수 있는 밑거름을 제공했다는 의의를 지닌다. 그러나 본 사업은 한국국제협력단이 외국의 교육 부와 협력하여 처음으로 실시한 교과서 보급 사업이라는 한계로 인해, 사업 진행 과정에서 다음과 같은 문제점이 드러났다. 따라서 해외 선진원조국가들의 교육원조사업의 사례 및 국제기구들에서 발간된 보고서의 내용과 국제협력단이 실시한 라오스 교과서 보급사업의 문제점들을 바탕으로 앞 으로 한국이 교과서 보급 사업을 추진해 나아가야 할 바람직한 방향을 제시하고자 한다. 


\section{가. 사전 준비 및 조사}

처음으로 실시하는 교과서 보급사업인 경우 다른 선진공여국들의 교과서 보급사업 및 라오스의 필 요에 대한 충분한 사전 조사를 통해 사업의 내용과 진행과정, 예상 원조금 등에 대한 보다 철저한 계획을 세웠어야 했으나, 사전 조사 및 준비가 부족했음이 사업 진행의 과정에서 드러났다. 라오스 에 대한 원조를 처음으로 제공할 당시에는 교과서 발간을 위해 교과서 인쇄 및 후가공 기계를 제공 하는 것이 사업내용의 전부였다. 하지만, 사업이 진행될수록 점차 교육과정개발에 대한 자문제공을 위해 수학과 과학 교육과정에 대한 전문가를 라오스로 파견하고 라오스 연수생을 한국으로 초청하 는 등의 사업이 계속적으로 추가되었다. 사전에 다른 해외선진국들이 교과서 보급사업을 어떻게 진 행하는지, 어떤 지원을 제공하는지 등에 대한 조사가 철저히 이루어졌다면 교육과정개발 자문단의 파견이나 연수생 초청 등의 내용은 충분히 사전 계획 하에 이루어질 수 있었을 것이다.

\section{1) 철저한 사전 준비 및 계획}

향후 추진될 교과서 보급사업은 다른 해외 선진국들의 사례 및 수원국의 현실과 필요에 대한 철저 한 사전 조사 · 수원국 정부와의 협의를 통해 사업내용과 진행과정 - 예상 원조금 등에 대한 보다 철 저한 계획을 세우도록 해야 한다.

\section{가) 관세와 세금면제}

라오스 사업의 경우 라오스가 교과서를 무상으로 제공받는 사업이므로 정부가 이윤 및 재정확보를 추구하지 않아야 함에도 불구하고 인쇄용지 및 잉크 수입 시 관세가 부과되었고 인쇄업체가 이윤을 취해 일부를 정부에 세금으로 납부했음이 드러났다. 따라서 향후에는 무상원조 사업과 관련된 원재 료 수입시 관세면제와 현지인쇄 업체 및 배송업체의 세금면제를 해당국 정부에 요구하여 무상원조 를 통해 정부가 경제적 이득을 취하기보다는 보다 많은 학생들에게 혜택이 돌아가도록 해야 한다.

\section{나) 공여국으로서 대한민국 인식}

교과서 뒷면 외부 표지에 우리나라 국기와 라오스 국기가 표시되고 교과서가 KOICA의 지원으로 보 급되었다는 문구가 들어가 있다. 그러나 거의 대부분의 중학교 학생들과 일부의 고등학교 학생들이 교과서를 두꺼운 종이로 씨워 사용해, 대한민국이 교과서를 무상으로 제공하였다는 사실을 인지하 는 비율이 낮은 것으로 나타났다. 따라서 교과서 내지에 동일한 내용을 인쇄해야 할 것인지에 대한 검토가 필요하다. 


\section{다) 학생들의 교과서 사용에 대한 적립금}

라오스 학교 방문결과 부상으로 제공되는 교과서의 경우에도 학교별로 학생들에게 교과서를 제공 하는 방식에 차이가 있음이 드러났다. 일부 학교들은 학생들에게 교과서 반환에 대한 적립금(약 $1,000 \mathrm{kip}=$ 약 150 원)을 받기도 하고, 일부는 무상으로 주기도 하였으며, 또한 일부 학교는 교과서 를 반납할 때 적립금을 돌려주기도 하고 다른 일부는 돌려주지 않기도 하는 등 교과서 반환을 위한 적립금에 있어서 일관성이 결여되어 있었다. 따라서 향후 교과서 제공사업 추진 시에는 해당 국가 의 교육부와 이에 대해 일관된 정책 방향을 어떻게 세울 것인지 사전 협의를 거쳐야 한다.

\section{2) 다양한 대안적 접근에 대한 검토}

교과서 보급사업을 실시함에 있어서 사업대상국이 개발도상국인 만큼 수원국이 교과서를 인쇄하 고 배분하기 위한 기본적인 설비마저도 제대로 갖추고 있지 않은 경우가 많다. 따라서 유네스코는 앞선 교과서 보급사업의 경험을 토대로 다음과 같은 대안적 접근법에 대해 소개하고 있다. 한국은 수원국가의 상황에 따라 다음과 같은 방법들도 고려하여 융통성 있게 시도해볼 수 있을 것이다.

\section{가) 교과서 생산 및 공급의 분권화(decentralization)}

지난 10 여 년간 일부 국가들은 교과서의 수급을 원활하게 하고자 교과서 생산과 배급을 분권화하는 정책을 실시했다. 유네스코 보고서(2005)에 따르면 교과서의 생산/공급 분권화 정책은 업체들 간 의 경쟁을 부추겨 교수방법적인 측면에서 보다 혁신적인 교과서의 개발을 촉진하고 교과서의 가격 을 낮춘다는 장점을 지닌다. 또한 각 지역 언어나 소수민족의 언어로 된 교과서 혹은 기타 부교재의 생산을 가능케 한다는 장점도 지니고 있다. ${ }^{19)}$ 생산의 분권화와 함께 교과서 가격이 절반으로 감소 되는 성과를 거둔 우간다(Uganda)가 이러한 정책으로 혜택을 본 대표적인 국가이다. 하지만, 일부 국가에서는 대형 교과서 생산업체가 시장을 지배하여 도리어 교과서 가격이 필요이상으로 비싸지 는 등의 비효율성을 드러내기도 하였다. 즉, 교과서 생산 및 공급을 분권화하는 경우에는 정부의 조 정과 감독이 필수적으로 뒤따라야 성공적인 결과를 거둘 수 있음을 암시한다. ${ }^{20}$

\section{나) 교과서 운송 및 배분을 위한 대안적 접근}

UNESCO 보고서(2005)는 ICT(Information and Communication Technology)의 발달과 함께 기존의 중앙정부주도의 교과서 인쇄 및 배분 방식 이외에 대안적인 방법들이 나타날 것이라고 제시

19) UNESCO(2005b). "A comprehensive strategy for textbooks and learning materials." http://unesdoc.unesco. org/images/0014/001437/143736eb.pdf

20) UNESCO(2005b). "A comprehensive strategy for textbooks and learning materials." http://unesdoc.unesco. org/images/0014/001437/143736eb.pdf 
하고 있다. 즉, '컴퓨터 인쇄 기능’은 지도서와 안내서, 심지어 교과서의 인쇄까지도 가능하게 하고 있으며, “인터넷” 을 통해서 교과서 인쇄 파일을 다운로드 받아 인쇄하는 것이 가능해진 것이다. 또 한, 인쇄된 교과서를 창고에 보관했다가 배송하는 것이 아니라 교과서 파일을 $\mathrm{CD}-\mathrm{ROMs}$ 에 담아 배송하는 것이 교통운반수단이 갖추어지지 않은 곳에서는 보다 나은 대안이 될 수도 있다고 지적한 다. 하지만, 이러한 기술적인 혜택을 누리기 위해서는 컴퓨터와 전기, 인터넷 연결을 위한 기반시설 이 요구되어지기 때문에 UNESCO는 이러한 시설을 개도국의 미개발지역에 마련해 '디지털 격차' 를 해소하기 위한 노력을 기울여오고 있다.

\section{나. 라오스 내 다른 국제기구들과의 공조}

앞서 해외 선진국들의 교육원조사업의 사례에서 소개되었듯이, 선진국들의 공적개발원조(ODA) 담 당 기구의 경우 국제기구들과의 공조 하에 사업을 계획하고 진행하는 경향을 보인다. 이는 한정된 원조자금을 효율적으로 사용해 최선의 결과를 달성하기 위함이다. 즉, 여러 국제기구들이 원조를 제공하고 있는 현실에서 산발적인 원조사업으로 인해 원조의 효과가 분산되는 것을 막기 위해서, 선진국 원조담당기구는 유엔과 유네스코가 제시한 '새천년 개발 계획'과 '모든 사람을 위한 교육'을 고려하여 사업을 계획하고, 진행 중인 사업에 자금을 제공하거나 혹은 사업의 일부 프로젝트에 참 여함으로써 수원국가의 교육현실이 최단기간에 개선될 수 있도록 협력하고 있다.

그러나 한-라오스 교과서 보급사업은 다른 국제기구 및 사업과의 연계나 공조가 충분히 이뤄지지 않은 상태에서 진행되었다. 더욱이, 우리나라는 교과서 원조 사업에 대한 경험이 부족하다. 따라서 우리나라가 국제기구들과 공조 하에서 사업을 진행했다면, 이들 기구들이 기존에 지니고 있던 라오 스 내 각종 교육관련 수요조사정보를 제공받아 보다 수월하게 사업 계획을 세울 수 있었을 것이며, 사업을 진행해나가는 방법에 대한 배움의 기회뿐 아니라 다른 국제기구들과의 네트워크를 형성하 는 기회로 작용할 수 있었을 것이다. 좀 더 구체적인 예를 들면 라오스 정부와 보급계약을 체결해야 하는데도 불구하고 제대로 된 영문계약서도 준비하지 않은 상태에서 시작되었다.

\section{1) 국제기구들과의 공조}

유네스코 및 유니세프 - 세계은행 - 아시아개발은행을 비롯한 여러 국제기구들이 개도국 정부와 협 력하여 지원하고 있는 다양한 사업들이 있는 만큼, 대외원조사업 경험이 부족한 대한민국은 우선 이들 국제기구들이 진행 중인 교과서 보급 사업에 함께 참여하거나 원조금을 제공함으로써 이들과 네트워크를 형성하는 것이 바람직하다. 앞서 제시되었듯이 교과서 보급사업은 단순히 교과서를 인 쇄해서 보급하는 것뿐만 아니라 교육과정에 대한 개정 및 교과서의 질 향상을 위한 부수적인 지원 이 함께 이루어져야만 한다. 국제기구들과의 공조는 적정한 수준의 사업규모를 유지하면서 그들의 
사업 진행 노하우를 배울 수 있는 기회로 작용할 것이다. 또한 점차적으로 한국의 ODA 사업 규모 를 늘려가면서 국제사회에서 공적개발원조 공여국(donor)으로서의 대한민국의 위상을 서서히 구축 해나가도록 해야 할 것이다.

\section{2) 범지역적 접근(Region-wide Approach)}

향후 교과서 보급사업은 세계 곳곳에서 진행되고 있는 각종 지역별 연합의 형성과 이의 파급효 과를 고려하여 이루어질 수 있어야 한다. 일본의 해외원조사례에서 소개되었듯이 일본은 아세안 (ASEAN, 동남아시아국가연합)을 하나의 큰 지역공동체로 인식하고, 이 지역 전체를 아우르는 원조 를 제공하고 있다. 이는 최근 $\mathrm{EU} \cdot \mathrm{NAFTA}$ 등 세계 곳곳에서 경제공동체가 형성되면서 지역별로 노동력과 자본의 흐름이 자유로워지고 역내 국가 간 경제에 대한 상호영향력이 증대되는 등 원조에 있어서도 범지역적 접근의 필요성이 높아지고 있기 때문이다. 즉 각 국가별 차별적인 문제점과 강 점에도 불구하고, 지역적 연계를 통해 원조 제공 시 자본과 노동이 이중으로 낭비되는 것을 막음으 로써 최대한의 성과를 거둘 수도 있다는 것이다. 또한 환경 - 범죄 - 질병 등과 같이 전 지구적 문제 해결을 위해서는 여러 국가들 간의 협력이 필수적인 상황이다. 교육 분야에 있어서도 범지역적 접 근이 가져올 수 있는 장점들이 있다. 예를 들어 교과서 내용의 개발 및 개정에 있어서 사회문화적으 로 공감대를 형성하고 있는 지역공동체들 간 위원회를 구성해서 자문을 제공해줄 수도 있고, 만약 역내 한 국가가 대외원조사업을 통해 교과서 인쇄 및 편집장비 · 연수 등을 제공받았다면 역내 장비 및 인력 측면에서 역량이 부족한 국가에게 도움을 제공함으로써 국가적 수요를 해결하는데 도움을 제공할 수도 있을 것이다.

\section{다. 교육과정개발 지원에 대한 검토}

처음 계획했던 라오스 교과서 보급사업의 내용은 단순히 교과서를 인쇄하고 보급함으로써 교과서의 이용가능성(availability)을 높이는데 국한되었다. 하지만, 라오스는 당시 초중등학교를 11년 학제 를 12 년제로 개편하는 작업이 진행 중에 있었다. 이에 따라 교육과정 개정 작업이 학제 개편 정책 과 연계되어 진행되고 있었다. 현재 새로 개정된 교육과정이 2009년도부터 연차적으로 확대 적용 되고 있다. 따라서 이에 대한 사전 조사가 있었다면 사업의 초기부터 교육과정개발에 대한 자문 및 교육 공무원에 대한 초청 연수를 통해 라오스 국가 교육과정의 개발 및 개정에 참여할 수 있고, 개 정된 교육과정에 부합하는 새 교과서를 라오스 중고등학생들에게 보급할 수 있었을 것이다.

\section{1) 한국 전문가의 참여}

교육과정개발과 교과서 집필에 한국 전문가들의 참여가 요구된다. 라오스의 경우, '국립교육연구원 
'National Research Institute for Educational Sciences, NRIES)을 중심으로 교육과정개발이 현재 진행되고 있으며 2009년까지 고등학교 교육과정 개발이 끝날 계획이다. 라오스는 교육과정 개발에 전문성이 부족하여 전문가의 도움이 요청되고 있다. 이번에 우리나라는 고등학교 교과서를 공급하였지만 현재 진행 중인 고등학교 교육과정 개편에 적극적으로 참여하지 않고 있다. $\mathrm{ADB}$ 의 경우 현지 교육과정 전문가를 상주시켜 중학교 교육과정 개발에 참여하고 있다. 우리나라도 오래 동안 교육과정을 개발해왔고 많은 경험과 지식을 축적하고 있으므로, 라오스 교육의 성장을 위해서 는 한국의 교육과정 개발 전문가들이 라오스 고등학교 교육과정 개편에 참여할 필요가 있다. 교육 과정 개발에 참여할 경우 전체 교육과정에 대한 이해를 통해 우리나라가 교과서를 보급하고자 하는 대상학년의 교육과정 내용을 분석/제안해야 한다.

교과서 집필에도 우리나라의 전문가가 참여한다면 교육과정과 교과서집필 간에 연계성 유지가 가 능하다. 또한 교과서 내용 중에 우리나라와 관련된 내용들의 합리성 여부 등을 검토할 수 있다. 예 를 들어, 현재 ‘동해바다 표기' 문제가 쟁점이니 만큼 집필과정에서 이를 수정 또는 병기(East Sea 와 Sea of Japan) 할 수 있다면 바람직할 것이다.

\section{2) 교사용 교재 개발 및 연수 제공}

교과서가 공급되면 이에 따른 교사훈련과 교사용 교재에 대한 필요가 뒤따르기 마련이다. 특히 새 교과서가 새로운 교육과정에 기초하고 있다면 기존교사들에 대한 재교육과 신규교사들에 대한 교 육이 실시되어야 하며, 학교에서 교사들이 수업에 사용할 수 있는 교사용 지도서와 교재도 개발되 어야 한다.

\section{라. 지속 가능한 지원}

유네스코 중간점검 보고서에 따르면, 교과서 제공사업에 대한 원조가 단기적이고 일회성의 프로젝 트에 그치는 경우가 많아 수원국가가 지속적으로 교과서를 인쇄할 능력을 키워주는데 있어서 많은 효과를 가져오지 못하고 있다고 한다. ${ }^{21)}$

실제로 라오스의 교육과정 개발은 체계적인 시스템과 이론적 근거를 갖추고 있지 못하기 때문에, 4 개월 과정의 자문만으로는 교과서 개정이 바람직한 방향으로 지속적으로 이루어지기 힘들 것이라 는 것이 라오스 교과서 보급사업에 참여한 전문가들의 의견이다. 하지만 지난 2 년간에 걸쳐 실시된 한-라오스 교과서 보급사업은 장기적인 원조 제공 계획 하에서 진행된 것이 아니라 일회성 성격으 로 계획·실시되었으며, 현재 예정된 후속 교과서 보급사업 또한 없는 실정이다. 따라서 라오스의 교육적 여건을 개선하기 위한 포괄적이고 장기적인 계획을 수립하여 지속적인 지원을 제공해나가

21) UNESCO(2008). "Education for all by 2015: will we make it? EFA Global Monitoring Report." http://unesdoc. unesco.org/images/0015/001547/154743e.pdf 
야 할 것이다.

\section{1) 포괄적이고 장기적인 접근}

교과서 보급을 통한 교육의 질 향상은 단기간에 성과를 낼 수 있는 사업이 아니다. 교과서를 자체적 으로 제작·보급하기 위한 기반시설 및 인력을 구축하는데 장기간의 시간이 소요됨은 물론이거니 와 양질의 교육이 제공되기 위해서는 효과적인 교육 관리 · 운영 체계의 적립을 위한 꾸준한 투자가 필수적이기 때문이다. 즉, [그림 4-1]에서 볼 수 있듯이 한 국가의 교육과정 및 정책 계발 - 교과서 인쇄 및 보급에 대한 국가적인 차원에서의 종합적인 설계를 해야 한다. 이를 위해 고위 교육 공무원 에 대한 지속적인 지원 및 연수·예비 및 현직 교사에 대한 양질의 연수제공을 통한 교사 질의 향 상 - 교과서 인쇄 및 편집 기술에 대한 지속적 지원 등 장기적이고 포괄적인 지원 속에서만 점차 수 원국의 독립적이고 자율적인 능력이 길러질 수 있는 것이다.

\section{[그림4-1] 바람직한 교과서 보급사업의 구조}

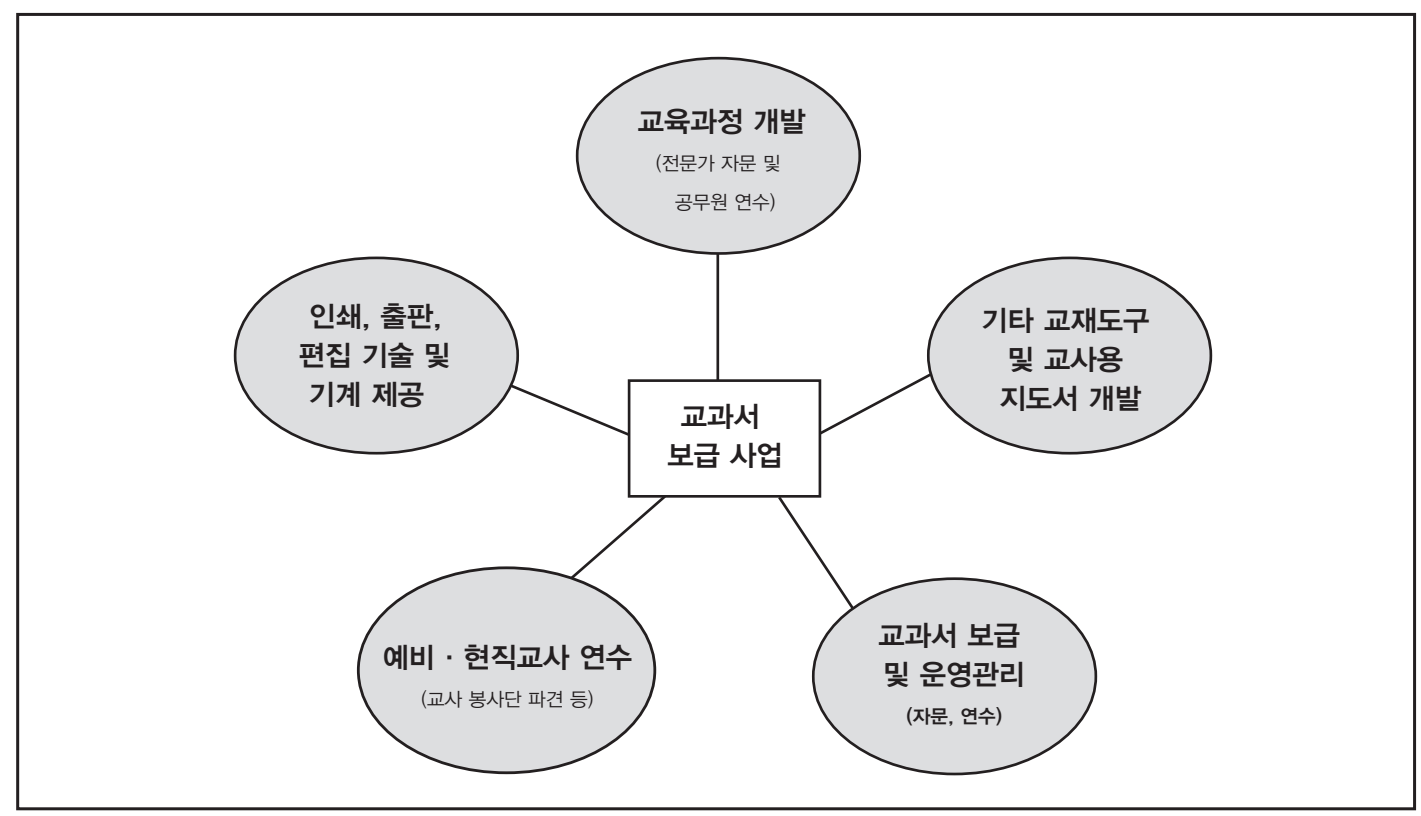

$\mathrm{UNESCO}$ 에서 발간한 '교과서 및 부교재에 관한 포괄적 전략' ${ }^{22)}$ 에 따르면, 모든 학생에게 질 높 은 교과서와 부교재를 제공하기 위해서는 아래의 [그림4-2]에서 보여지 듯 '정책(Policy)'과 '교과

22) UNESCO(2005b). "A comprehensive strategy for textbooks and learning materials." http://unesdoc.unesco. org/images/0014/001437/143736eb.pdf 
서 및 부교재 질(Quality)' ·입수 가능성(availability)'이라는 세 요소에 대한 고려가 함께 맞물려 진행되어야 한다. 이 보고서에 따르면, 교육과정과 정책 평가 - 개발 담당자들에게 ‘적절한 연수’를 제공함으로써 범국가적 필요뿐만 아니라 각 지방의 특성과 언어에 따른 필요도 함께 반영한 교육 과정과 교육정책이 개발되어야 한다. 그리고, 능동적으로 학습하고 비판적으로 사고할 수 있는 책 임감 있는 시민으로 성장할 수 있도록 양질의 교육내용이 제공되어야 하며, 교과서의 입수 가능성 (availability)을 높이기 위해서는 교과서를 인쇄 · 운반 · 배분하는 기술이나 기반시설에 대한 지원 뿐만 아니라 기술을 갖춘 인적자원의 개발도 동시에 이루어져야만 한다. 즉, 교과서를 '계획’하고 '개발'하는 단계에서부터 ‘배분’과 ‘배송'의 최종단계까지를 아우르는 “포괄적인” 기술 지원과 자문 이 제공되어야만 확실한 사업의 성과를 달성할 수 있다. ${ }^{23)}$ 즉 교육 정책과 교과서의 질 · 교과서의 입수가능성이라는 세 요소의 개선을 위해서는 포괄적이고 장기적인 계획을 바탕으로 한 접근이 필 요하다.

[그림4-2] 교과서와 기타 부교재를 위한 유네스코의 전략 ${ }^{24)}$

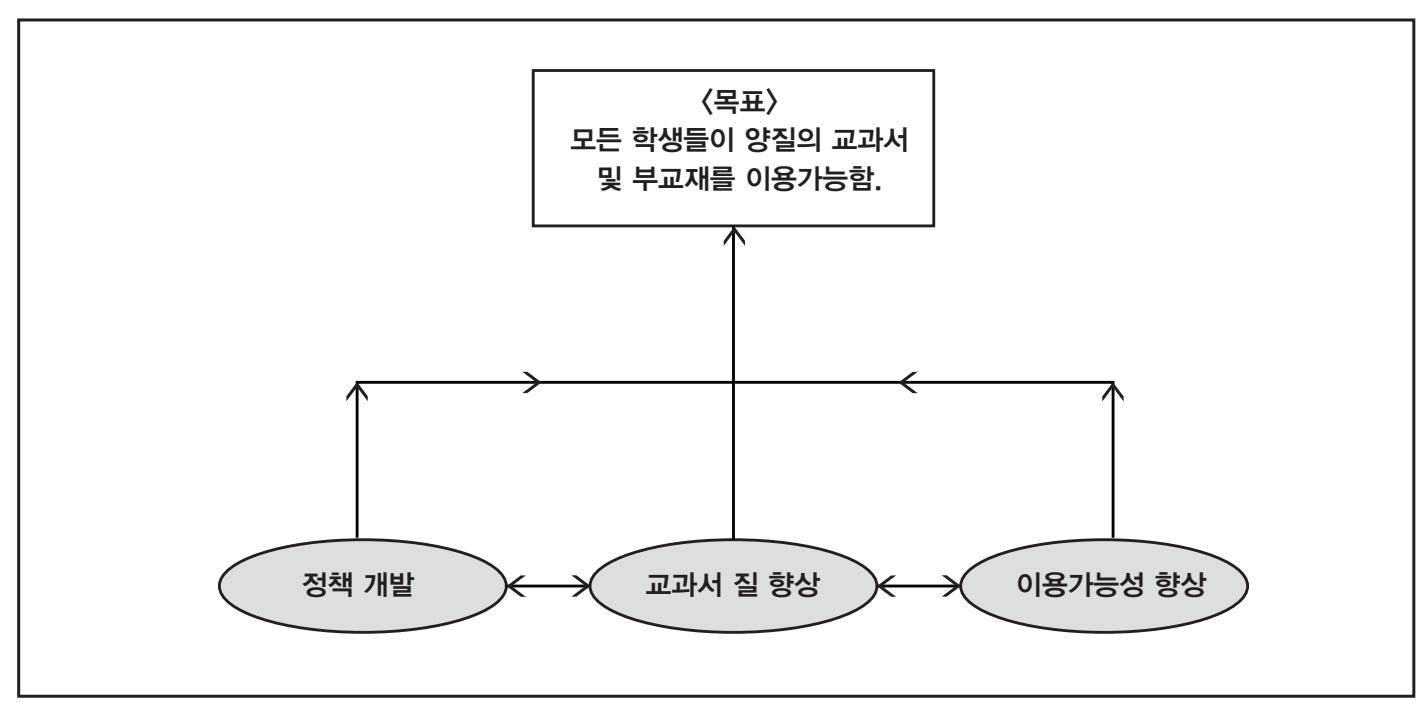

\section{2) 직업교육훈련 교과서 보급사업}

한국은 50 년이라는 짧은 시간 안에 세계최빈국에서 세계경제 12 위의 대국으로 성장했으며, 이러한 경제성장 모델은 다른 개발도상국가들에게 벤치마킹 대상으로 여러 차례 소개가 된 바 있다. 그리

23) UNESCO(2005b). “A comprehensive strategy for textbooks and learning materials.” http://unesdoc.unesco. org/images/0014/001437/143736eb.pdf

24) UNESCO(2005b). 
고 이러한 한국의 놀라운 경제성장의 원동력은 경제발전의 각 단계에 상응하는 인력개발이었다. 따 라서 많은 개발도상국들이 한국의 경제성장모델과 교육을 통한 지원전략에 대해 배우고 싶어하는 것이 현실이다.

우리나라는 그동안 일반교육보다 직업교육훈련에 비교우위를 갖고 있다고 평가되어왔으며, 직업훈 련원 및 직업학교 설립 등의 많은 원조사업을 추진해왔다. 그러나 라오스를 포함한 많은 개도국들 은 직업교육훈련분야 학생들이 공부할 수 있는 교과서가 제대로 공급되지 못하고 있다. 과거의 경 험과 연구 결과들은 직업교육훈련에서도 당장 사용할 수 있는 기술도 중요하지만 개인들이 향후 기 술진화에 적응할 수 있으려면 자기학습능력을 배양하는 것이 중요하다고 강조하고 있으며, 교과서 는 이를 위한 기본항목이다. 따라서 직업교육훈련 교과서 보급에 대해서도 검토해 볼 필요가 있다.

이상에서 앞으로 한국이 교과서 보급사업을 추진해나갈 바람직한 방안을 모색해보았다. 위의 내용 을 정리해보면, 철저한 사전 조사 및 준비를 통해 수원국의 필요에 대해 정확히 파악하고 이를 바탕 으로 장기적이고 포괄적인 계획을 수립하여 다른 국제기구 및 사업들과 공조함으로써 체계적이고 효율적인 원조가 이루어질 수 있도록 한다는 것이 그 핵심이다.

이는 비단 교과서 보급 사업뿐만 아니라 공적해외원조사업 전반에 해당되므로 향후 대외원조는 이 러한 원칙을 바탕으로 보다 효율적이고 효과적으로 이루어질 수 있어야 할 것이다. 


\section{참고 자료}

\section{1. 국내문헌}

코이카 업무자료(2007), “라오스중등학교 교과서 보급사업 실시협의 결과보고서”.

\section{2. 국외문헌}

AusAID(2009). “Annual Reports(1999-2008).”

AusAID(2008). “Education Annual Thematic Performance Report 2007-2008.”

AusAID(2007). “Better Education: A Policy for Australian Development Assistance in Education."

AusAID(2006). "Statistical summary 2004-2005: Australia's international development cooperation."

JICA(2008). “Annual Reports (2001-2007).”

LAO PDR(2007). “Sector-wide approachin education sector development, Interim Report(Draft)".

Ministry of Education(2005). “Annual Bulletin, 2004-2005”, LaoPeople's Democratic Republic."

UNESCO(2008). "Education for all by 2015: will we make it? EFA Global Monitoring Report.”

UNESCO(2005). “Textbook quality improvement program: support to basic education in Iraq."

UNESCO(2005). “A comprehensive strategy for textbooks and learning materials.” 